\section{Traços de um país em transição: a Constituição de 1988 nas charges do Correio Braziliense}

[Traces of a country in transition: The Constitution of 1988 in Correio Braziliense's political cartoons]

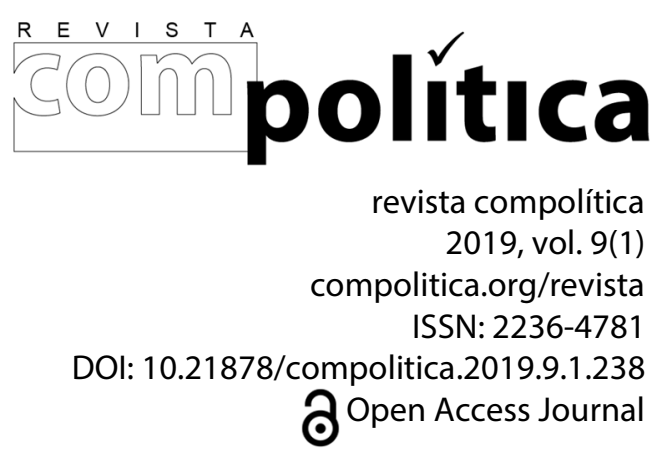

\author{
Paulo Henrique Soares de Almeida \\ Universidade de Brasília \\ [Brasília University]
}

\section{Célia Maria Ladeira Mota}

Universidade de Brasília

[Brasília University]

\begin{abstract}
Resumo
O artigo analisa as charges publicadas no jornal Correio Braziliense sobre a promulgação da Constituição Federal de 1988. Utilizando como metodologia a Análise Crítica da Narrativa, tal como proposta por Motta (2013), o objetivo é investigar os significados e efeitos de sentido produzidos e compreender como essas narrativas interpretaram esse acontecimento histórico. O trabalho sugere que a Carta Magna foi representada nas imagens como um símbolo de esperança, uma nova chance de transformação do Brasil. O artigo também aponta que as charges vão muito além do humor ao evidenciarem as manobras políticas da época.
\end{abstract}

Palavras-chave: Constituição Federal de 1988, charge, narrativa jornalística, representação.

\begin{abstract}
The article analyzes the political cartoons published in the newspaper Correio Braziliense about the promulgation of the Federal Constitution of 1988. Using as a methodology the Critical Narrative Analysis as proposed by Motta (2013), the objective is to investigate the meanings and effects of senses produced and understand how these narratives represented this historical event. The work suggests that the Constitution was represented in the images as a symbol of hope, a new chance for Brazil's transformation. It also shows that the cartoons go far beyond humor, unveiling the political maneuvers of the time.
\end{abstract}

Keywords: Federal Constitution of 1988, political cartoons, journalistic narrative, representation. 


\section{Traços de um país em transição: a Constituição de 1988 nas charges do Correio Braziliense}

Paulo Henrique Soares de ALMEIDA

Célia Maria Ladeira MOTA

s imagens constituem uma preciosa fonte de informação que, a cada dia, é mais
visitada e explorada pelas mais diversas disciplinas acadêmicas. Cientistas e
historiadores têm, por meio delas, acesso a dados que complementam os documentos textuais, nos contestam, ou apontam para novas formas de interpretar fenômenos sociais. De acordo com Burke (2017), o uso de imagens, em diferentes períodos, permite testemunharmos antigas formas de religião, de conhecimento, de crença e cultura. Entretanto, o autor adverte que, antes de tentarmos ler as imagens entre as linhas e de usá-las como evidência histórica, é preciso compreendê-las pelo seu sentido.

A imagem é um documento quando ela nos conta uma história, narra e registra o gênero, a arquitetura, a vida social, os comportamentos, o cotidiano, a moda, o estilo de vida e os hábitos de uma época. Jacques Aumont (2011), em sua obra L'image, explica que tudo o que sabemos sobre a pré-história é resultado da pesquisa de antropólogos e historiadores, que reconstruíram a cultura do homem a partir de objetos e pinturas encontradas no interior de grutas e cavernas em várias partes do mundo. De acordo com Aumont, "a imagem documenta, e falo com poder de convencimento, pois mostra aquilo de que nos está a informar, e de maneira próxima da realidade" (Aumont, 2011, p. 134). Nesse vasto campo de estudo sobre imagens, trataremos, nesta pesquisa, sobre um aspecto que acreditamos ser negligenciado: a charge como narrativa e sua importância como informação e documento histórico.

Do francês charger, significa: carga, carregar ou exagerar. A charge pode ser definida como "uma forma de representação pictórica de caráter burlesco e caricatural, em que se satiriza um fato específico, tal qual uma ideia, situação ou pessoa, em geral de caráter político e do conhecimento público" (Fonseca, J., 1999, p. 26). Ao fazer a representação de algo, a charge tende a destacar o estereótipo, o excessivo, permeando as figuras de linguagem como metáfora, ironia e hipérbole. É, portanto, “um instrumento de crítica e 
arma retórica de combate, bem como na defesa e divulgação de ideologias, princípios e programas políticos” (Miani, 2012, p. 39).

Uma das práticas de construção de significados sobre os acontecimentos, consideramos a charge como um rico gênero argumentativo, uma ação retórica, que revela as relações de poder, a posição do autor e o jogo de persuasão. Por meio de uma narrativa satírica e híbrida, que mistura elementos da realidade com o imaginário, a charge argumentativa se posiciona, fere, punge, denuncia e nos possibilita reflexões sobre um determinado tempo e representações, sejam elas políticas, econômicas ou sociais. Nesse gênero é possível encontrar os mitos, fábulas, cultura, o modo de vida de uma sociedade e sua época. Ao narrar e representar um acontecimento, ela tende a destacar formas simbólicas, que contribuem para moldar o imaginário coletivo sobre um país, cultura, organização e política. "Através de sua análise podem-se perceber as estratégias utilizadas pelos vários segmentos envolvidos nos jogos de poder e manipulação de que consciente ou inconscientemente somos atores e alvos" (Flôres, 2002, p. 11). Nesse caminho, recuperar e confrontar os sentidos produzidos por essas imagens, que se aproximam e se afastam da realidade, é fundamental para compreendermos suas reais intenções e ideologias, muitas vezes, percebidas apenas como uma piada. "O humor não pretende colocar as pessoas a rir. Fazer rir é tarefa do cômico. O humor pretende levar as pessoas a pensar nos acontecimentos. Trata-se de um humor tão inteligente que o espectador fica a pensar na mensagem" (Fernandes, 2016, p.2016). Partindo desse princípio, este artigo consiste em analisar três dessas narrativas publicadas no jornal Correio Braziliense, sobre a promulgação da Constituição de 1988, a fim de investigar os significados e efeitos de sentidos produzidos nessas imagens.

Símbolo de esperança, após um longo período de ditadura, a elaboração de uma Constituição retomou o sonho do Brasil como país do futuro. Esta Carta não só restabeleceu a inviolabilidade de direitos e liberdades básicas no país, como pretendeu instituir uma vastidão de preceitos progressistas, como a igualdade de gênero, a criminalização do racismo, a proibição da tortura e tantos outros direitos sociais, como educação, trabalho e saúde. Nesse contexto, as perguntas que colocamos são: como as charges representaram esse acontecimento histórico, que foi a promulgação da Constituição Federal de 1988 ? 
Como essas imagens projetaram os sentidos de mudança e redemocratização brasileira idealizados pela nova Carta?

\section{Representação e cultura visual}

Segundo Hall (2009), representação significa utilizar a linguagem para informar alguma coisa com sentido, sobre algo ou alguém, a partir de símbolos, palavras, músicas, imagens, fotos, entre outros. Em suma, a representação conecta significado e linguagem com a cultura. "Dizer que duas pessoas pertencem à mesma cultura, é dizer que, as mesmas pessoas interpretam o mundo e se expressam, aproximadamente, da mesma maneira" (Hall, 2009 , p. 2). Esses quadros de referência, segundo Hall, funcionam como moldura ou mapas culturais, que constroem significados e direcionam a forma como os códigos serão interpretados. Essa relação está associada ao que Hall destaca como circuito cultural, onde as práticas - produção, circulação, consumo, reprodução e identidade - estão conectadas entre si, em círculo, porém independentes. Nesse circuito, a forma como recebemos informações sobre determinado tema ou área de atividade social, bem como a maneira como interpretamos essa mensagem, está diretamente relacionada com os discursos dos meios, que produzem sentido e significados e que serão decodificados e reproduzidos no campo social.

Desse modo, a cultura da mídia fornece material importante, com que muitas pessoas constroem o seu senso de classe, etnia, nacionalidade, sexualidade, da relação entre nós e eles. De acordo com Kellner (2001), as narrativas veiculadas pelas mídias fornecem os símbolos, os mitos e os recursos, que ajudam a constituir uma cultura comum compartilhada em grupo. Ecoando o autor, Ladeira Mota (2012) afirma que a imagem tem um papel importante como referência e índice de um significado dominante, contribuindo para o que pode ser chamado de cultura visual: "uma prática de olhar o mundo mediado que nos cerca, compartilhando sentidos e narrativas sobre nós mesmos" (Mota, 2012, p.197).

Ladeira Mota (2012) adverte que uma imagem simplesmente não se transforma em cultura visual até que seja visualizada. Visualizar, segundo a autora, não é simplesmente produzir objetos visíveis, mas comprometer a vida cotidiana em uma cultura de commodity, que 


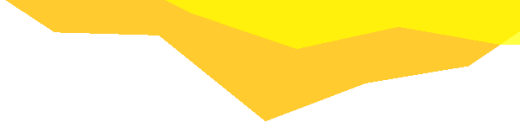

demanda o nosso olhar para gerar valor para mais alguém. "Com isso, a visualização se apropria do fazer histórico e se transforma na principal referência dos significados que vamos construindo sobre o mundo que vivemos" (Mota, 2012, p. 199).

A cultura visual está incessantemente mediada em todos os lugares: no cinema, nas telas da TV ou do computador, nos tablets, nas inúmeras câmeras de segurança instaladas nas ruas das cidades, nos games digitais, no Facebook, Instagram, vídeos do YouTube e outras infinidades de meios, inclusive em nosso objeto de estudo, as charges. Essas ilustrações são culturas visuais ou produções midiáticas complexas, que, ao interpretarem uma realidade específica ou um acontecimento, incorporam discursos sociais e políticos que ajudam a constituir a visão de mundo, pensamentos e ações do indivíduo. Elas escancaram a história, o mito e o exagerado. Elementos, estes, que se perpetuam e se cristalizam na memória coletiva. Suas análises devem ser observadas por meio de uma leitura crítica, capaz de articular relações, não só com a economia e a política, mas com todo o contexto social em que elas foram produzidas.

\section{Charge, linguagem e narrativa}

A produção da realidade pelas charges está diretamente ligada com a linguagem, mas isso só é possível por conta das objetivações da expressividade humana, conhecida e criada dentro de um mundo comum ou familiar. É a linguagem que marca as coordenadas da vida em sociedade e preenche essa vida de objetos cheios de significação. Embora icônica, a charge é uma representação. Uma interpretação ou ponto de vista do autor, que participa da produção da realidade. Relato de um acontecimento produzido em uma atividade mimética, que não se limita a copiar, mas a reinventar criativamente o real, em um diálogo permanente com os demais atores sociais. Ao relatar um acontecimento, o chargista não é responsável apenas pela transmissão de informação, mas também por sua recontextualização. Ele recorta uma parte da realidade, enfoca um ponto de vista e o transforma em algo novo. Segundo Quéré (2005), é preciso, portanto, observar o poder hermenêutico do acontecimento, com sua capacidade reveladora de dar significado aos fatos da vida cotidiana. Fatos que possuem uma história, um determinado contexto. É para facilitar essa decodificação, que a teoria das representações sociais destaca a ancoragem 
como aquilo que classifica e nomeia, tornando familiar o que lhe é apresentado. É o saber dos fatos para interpretar o código, sendo a compreensão da realidade o caminho primário para que um indivíduo participe do processo e se torne parte de uma sociedade e cultura (Berger; Luckmann, 2012).

A linguagem da charge é um sistema de representação que constrói e transmite sentido. "Ela significa. Ao fazê-lo, retoma sua característica de signo, que existe para representar nossos conceitos, ideias ou sentimento. E como linguagem, ela se torna uma prática significante” (Mota, 2012, p. 204). Sua interpretação e compreensão passa pela análise desse texto multimodal, cuja representação seria o significante e sua interpretação, o significado. Embora a imagem tenha um papel importante e atue como referência e índice de um significado dominante, a charge como narrativa vai se apoiar sempre em uma narrativa maior, que são as notícias diárias, que têm como matéria-prima os acontecimentos.

De acordo com Motta (2013), narrar é uma experiência inata na existência humana. As narrativas são mais que representações, são estruturas que dão sentido e significação à vida. São relatos de acontecimentos, que recriam o passado, vivem o presente e o futuro. Segundo Motta (2013), ao narrar, alguém está explorando na sua imaginação possíveis desenvolvimentos (reais ou ficcionais) das condutas e comportamentos humanos, que os teóricos chamam de atividade mimética ou imitação. É a recriação de algo já existente ou já explorado. "Quando escutamos, assistimos ou lemos uma estória, estamos na estória e recriamos a sua significação a partir da relação que fazemos com os nossos próprios valores e nossa memória cultural" (Motta, 2013, p. 73).

Motta (2013) classifica as narrativas como factuais e imaginárias, sendo o relato jornalístico, por excelência, um exemplo de narrativa factual. Segundo o autor, a grande maioria das notícias do dia a dia é redigida em terceira pessoa, numa linguagem descritiva, direta e objetivada, onde a intenção é produzir o efeito de realidade, a veracidade. "São as chamadas hard news das editorias de política, economia, internacional, cidades, por exemplo, escritas em linguagem descritiva clara, direta, enxuta, que se quer objetiva" (Motta, 2013, p. 96). Entretanto, de acordo com Motta, a lógica narrativa só se revelará nas 
duras e cruas notícias do dia a dia se observarmos como elas lidam com o tempo e o organizam.

\begin{abstract}
A lógica e a sintaxe narrativas só despontarão se pudermos reconfigurar os relatos como unidades temáticas, intrigas que contenham princípio, meio e final de uma estória única. Reunindo informações dispersas sobre um mesmo tema ou assunto (que podem estar separadas por intervalos de dias, semanas ou meses no noticiário), o analista junta as pontas, encontra os conectivos e encadeamentos narrativos, os antecedentes e consequentes, recompõe a serialidade, a sequência e a continuidade da intriga, como o leitor faz corriqueiramente (Motta, 2013, p. 97).
\end{abstract}

A narrativa jornalística, portanto, está voltada para os fatos. Ao buscar o conceito de fatos, Fonseca V. (2010) relaciona o termo com acontecimento e notícia. A autora parte do princípio, de que a matéria-prima do jornalismo é a informação. "Essa informação, no entanto, precisa apresentar determinadas características para ser transformada em notícia, e vários autores já se ocuparam de relacioná-las, podendo-se citar, por exemplo, as de veracidade, atualidade e interesse público" (Fonseca, V., 2010, p. 169). Para o pesquisador Adriano Duarte Rodrigues (1993), "acontecimento é tudo aquilo que irrompe na superfície lisa da história, entre uma multiplicidade aleatória de fatos virtuais" (Rodrigues, 1993, p. 27). Ao se tornar acontecimento jornalístico, o fato é recontextualizado e seus significados sociais ganham novos significados a partir do discurso jornalístico materializado em novas narrativas. A Constituição Federal de 1988, por exemplo, foi um acontecimento histórico interpretado e ressignificado, também, nas charges jornalísticas.

Partindo dos conceitos citados, compreendemos a charge como uma narrativa satírica que, ao contar uma história, percorre todo o caminho de uma narração situada no tempo e espaço: com enredo, clímax, intriga e personagens. Sua comunicação é realizada por meio de um sistema de signos, que têm entre suas características a coesão, a coerência, a intencionalidade, a informatividade e a intertextualidade. Ela reforça o texto jornalístico produzido nas hard news, mas gera um produto cultural novo e diferente. É um dos recursos jornalísticos usados para produzir significados sobre um acontecimento, no qual o efeito real é o resultado da interação de dois códigos: o linguístico e o visual.

Assim como explora o factual, a narrativa da charge também extrapola a criatividade, o imaginário e o mito, na busca da construção social da realidade. Ela está impregnada de 
valores subjetivos, estéticos e morais, indo além dos limites de uma narrativa jornalística textual padrão, para prender ainda mais a atenção do leitor e conquistar os efeitos de sentidos almejados. Por meio de figuras de linguagem, como metáfora, ironia e hipérbole, performatiza personagens que representam seres humanos concretos, em uma estrutura interna de conexão que se revela em um espaço temporal. O tempo ajusta os fatos entre si, configura a cronologia do enredo, traz à tona o conflito, a intriga e as personagens. $\mathrm{O}$ tempo também é usado por Romualdo (2000) em sua definição de charge. Segundo o autor, enquanto o cartum é atemporal, a charge, por focalizar uma realidade específica, se prende mais ao momento.

\section{Metodologia}

Como a leitura da charge requer conhecimentos que envolvem contexto social, fatos históricos, personagens, enredo, relações de poder, política e linguagem, adotamos como caminho metodológico a Análise Crítica da Narrativa, proposta do professor Luiz Gonzaga Motta (2013). O objetivo é estudar não apenas a mensagem produzida, mas também como a promulgação da Constituição de 1988 é contada, destacando as representações das personagens, figuras de linguagem (como metáfora, metonímia e ironia), o cenário, o enredo, o conflito, o contexto, os objetos de cena e a dramatização. Todos esses elementos são fundamentais para compreendermos os efeitos de real e sentidos construídos. Portanto, percorrendo a análise crítica da narrativa sugerida por Motta (2013), o estudo das charges aqui recortadas segue três caminhos interligados:

a) Plano de expressão: discurso e linguagem. Onde a imagem se aflora e captura o olhar do espectador. Aqui, trabalhamos a linguagem verbal e não-verbal da charge, que se relaciona diretamente com a notícia e os elementos da realidade. Observamos ainda as figuras de linguagem, como ironia e hipérbole, muito utilizadas nas charges.

b) Plano da história: é o plano virtual da significação e do conteúdo, no qual estudamos o dito e não dito da narrativa, o enredo, o drama, e as críticas que aparecem e as personagens. 
c) Plano da metanarrativa: onde veremos como essas representações remetem à memória e à identidade brasileira. É o plano que mergulha nos significados e sentidos cristalizados pela tradição histórica, social e política do espaço em que a imagem foi construída.

\section{Análise dos dados}

Para responder as perguntas deste artigo, selecionamos três charges feitas pelo cartunista Kácio, publicadas na editoria de Opinião do Correio Braziliense, veículo de comunicação fundado em 1960 por Assis Chateaubriand e hoje pertencente aos Diários Associados. O veículo foi escolhido para o recorte porque, além de trazer a charge periodicamente em suas páginas, é um jornal significativo sediado em Brasília, capital do país, cenário político analisado.

Como narrativas, foram recortadas imagens divulgadas em datas relevantes da história (a) a instalação da Constituinte, b) a promulgação da Constituição e c) o pós-acontecimento, onde o início, o clímax e o desenrolar dos fatos configuram a cronologia do enredo e o fio condutor da narrativa. A proposta foi buscar nas três imagens publicadas separadamente a construção da intriga e os pontos de virada que unem essas ilustrações, conectando os eventos em sequência para desvendar os sentidos pretendidos pelo autor.

O ponto de partida é a data da instalação da Assembleia Nacional Constituinte, oficialmente no dia $1^{\circ}$ de fevereiro de 1987, durante o governo de José Sarney, do Partido do Movimento Democrático Brasileiro (PMDB) (atual Movimento Democrático Brasileiro - MDB), e primeiro presidente civil desde o golpe militar de 1964. Composta por 559 congressistas sendo 487 deputados e 72 senadores - a Assembleia teve como presidente o deputado Ulysses Guimarães (PMDB), principal líder parlamentar de oposição aos governos militares.

A Constituição Federal de 1988 é a sétima desde a independência no Brasil, e ficou conhecida como a "Constituição Cidadã", pois marca a conquista da democracia entre todos os cidadãos do país, após anos sob um regime de ditadura militar. O historiador Vitor Amorim de Angelo lembra que, durante 20 meses, a Assembleia esteve aberta a propostas 
de emendas populares. "Até o encerramento dos trabalhos, foram mais de 120 propostas de emendas constitucionais nas mais diversas áreas, reunindo cerca de 12 milhões de assinaturas (Angelo, 2007).

\title{
Esperança
}

A busca pela redemocratização do Brasil por meio da nova Carta Magna, fez crescer no país a esperança de um novo tempo. Tanto que o editorial do jornal Correio Braziliense, publicado em 2 de fevereiro de 1987, definiu a Carta como "passaporte para o terceiro milênio".

\begin{abstract}
A nação será passada a limpo nos próximos meses. Todos os grandes questionamentos nacionais terão que ser apresentados, discutidos e votados. É longa a lista dos temas e problemas que deverão ser incorporados à lei básica do país. A distribuição da renda nacional, a presença do fisco, os direitos dos cidadãos, os desníveis regionais, a União, os Estados, os Municípios, o Congresso Nacional, os abusos do poder econômico são alguns grandes desafios a serem atualizados em nova versão constitucional (Correio Braziliense, 2 fev. 1987. p.4)
\end{abstract}

É esta, também, a mensagem principal da charge publicada no dia 2 de fevereiro de 1987 no Correio Braziliense (Figura 1), um dia depois da instalação da Assembleia Constituinte. Sem traços de humor, a imagem em preto e branco é a linguagem visual do editorial, dispensando a interferência do narrador ou qualquer fala das personagens. A representação metafórica da bandeira do Brasil como o nascer de um novo sol é um importante signo, índice de esperança e renovação. Nota-se que o Congresso Nacional aparece pequeno diante dessa luz, mas como destino final de um caminho que será percorrido pelos brasileiros, em busca de novas leis, respeito e dignidade.

As personagens - elementos-chave na projeção da história e figuras centrais da narrativa (Motta, 2013) - compõem o frame dramático da cena. A família, representada na charge por um casal abraçado com o filho e seu carrinho de brinquedo, reforça o sentido de busca por um futuro melhor entre as gerações. É uma imagem que reconstrói a memória do livro Brasil, país do futuro, escrito pelo austríaco Stefan Zweig, em 1941: 
O Brasil é um país que odeia a guerra, não tem desejo de conquistar territórios, não possui tendências imperialistas. Nunca a paz do mundo foi ameaçada pela sua política e, mesmo numa época de incertezas, não é possível imaginar que o princípio de sua ideia nacional, esse desejo de entendimento e de acordo, se possa jamais alterar. Por isso, no Brasil repousa uma das nossas melhores esperanças de uma futura civilização (Zweig; 1941).

Figura 1: charge publicada no Correio Braziliense em 2/2/1987.

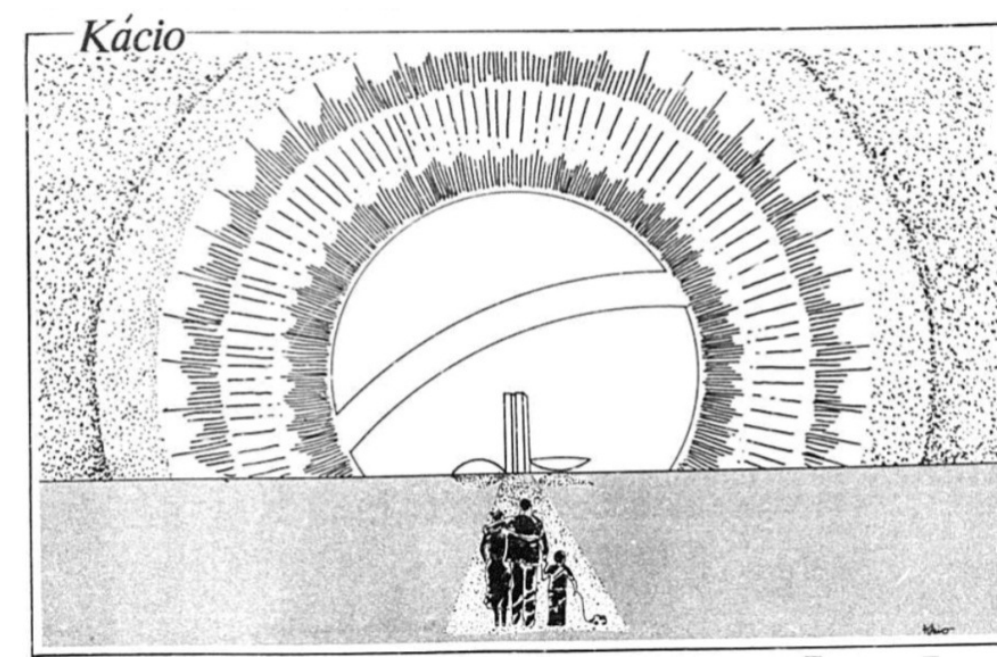

Autor: Kácio.

O sentido de esperança, destacada na charge, contribui na construção da identidade nacional, onde a ideia é de que o brasileiro não desiste nunca e está sempre caminhando em busca de algo que ainda não chegou, mas está por vir. Narrativas da nação como essa, contada e recontada na mídia e cultura popular, simbolizam ou representam as experiências partilhadas, as perdas, os triunfos e os desastres que dão sentido à nação. No caso do Brasil, essa ênfase nos lembra do "gigante adormecido em berço esplêndido", sempre pronto para se levantar e acordar nos grandes acontecimentos históricos. Observando, ainda, a estética da narrativa, de tão harmoniosa, ordenada e perfeitamente planejada, chega a representar a frase "ordem e progresso", que não aparece na ilustração da bandeira, mas pode ser vista por toda a cena.

O equilíbrio é quebrado, quando surge o conflito nas próximas imagens publicadas. A partir daí, as ilustrações sobre a Carta vão nos revelar o drama, o suspense e o clímax, até compor 
a totalidade da história. Um dos pontos altos da narrativa pode ser visto na segunda charge analisada (Figura 2).

\section{Salvação para todo o caos}

Publicada no dia 5 de outubro de 1988, no dia da promulgação da Constituição, a imagem (Figura 2) é uma reinterpretação de uma fotografia estampada na capa do Correio Braziliense, no dia 4 de outubro de 1988 (Figura 3), mas que é ressignificada. Ao misturar elementos da fantasia e realidade para se aproximar do leitor, o chargista vai além e revela o não dito na imagem da capa publicada no dia anterior. Na charge, o deputado Ulysses Guimarães dentro de um buraco, sem o sorriso da foto original, mas com os olhos cansados, levantando a Constituição como um troféu e com as mãos trêmulas, foi a maneira como o chargista interpretou o acontecimento e o reverberou na editoria de Opinião do Correio Braziliense. Diferente da Figura 1, a narrativa, que antes olhava apenas para um futuro radiante, agora é mais satírica e ridiculariza.

Figura 2: charge publicada no Correio Braziliense em 5/10/1988.

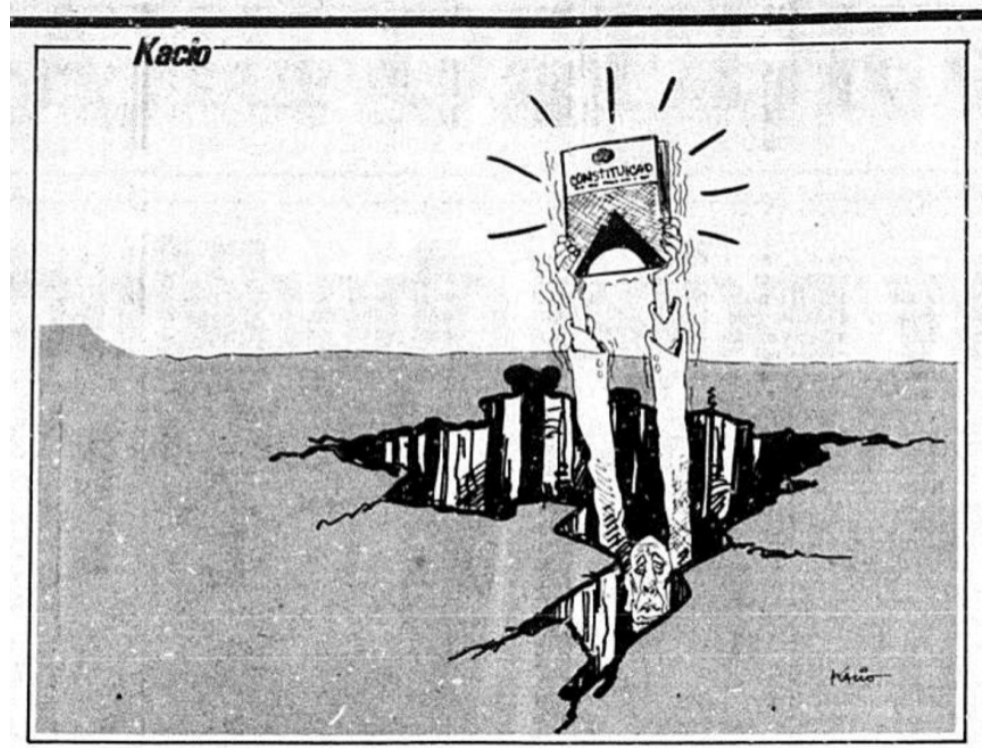

Autor: Kácio. 
A representação do mapa do Brasil como buraco é um índice de como era o país na época. O início dos anos 80 foi marcado pela reabertura política, após o golpe militar de 1964. A pressão por eleições resultou, em 1984, no Movimento "Diretas Já", o qual buscou a participação da sociedade civil na escolha dos governantes, e levou milhares de pessoas às ruas de diversas capitais. Em 1985, mesmo indiretamente, o presidente Tancredo Neves (PMDB) foi eleito, mas adoeceu no dia da posse e faleceu pouco tempo depois, levando José Sarney, seu vice, a assumir o governo. Sarney havia apoiado a ditadura, foi senador pela Aliança Renovadora Nacional (ARENA) - partido político criado em 1965 e apoiador do governo militar - e depois presidente do Partido Democrático Social (PDS).

Do ponto de vista econômico, durante o governo Sarney, os altos índices inflacionários, a crise econômica (com congelamento dos salários e preços) e a dívida externa, estampavam os noticiários diariamente. Por conta deste contexto econômico conturbado, houve tentativas de reformas e diversos planos econômicos foram adotados, como o Plano Cruzado, Plano Bresser e Plano Verão, mas todos eles fracassaram e a crise econômica se agravou no final do governo Sarney, com uma escalada da inflação anual que chegou a um patamar maior que 1.800\%, em 1989 (Cancian, 2006). Na cultura, músicas e programas de TV questionavam a política brasileira. No ar pela Rede Globo, a novela Vale Tudo convidava o Brasil a mostrar a sua cara e perguntava se valia a pena ser honesto no país. É nesse contexto que o suspense da história se aflora na charge. 
Figura 3: capa do Correio Braziliense, publicada em 5/10/1988.

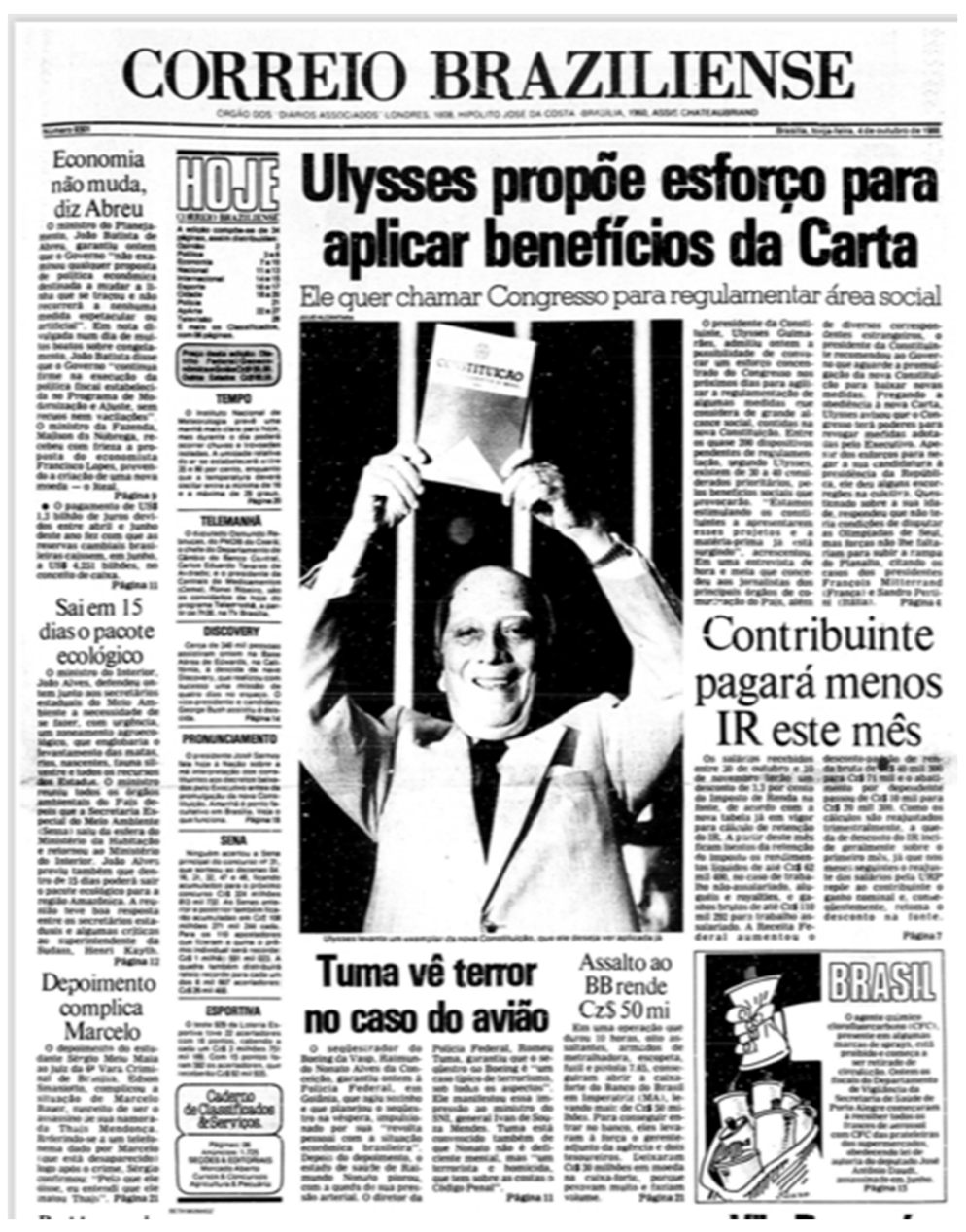

Fonte: Correio Braziliense.

Em vista disso, a Constituição de 1988 foi traçada como a salvação para todo o caos. Entre as principais conquistas promovidas pela nova Carta Constitucional, estão: o restabelecimento das eleições diretas para presidente da República, governadores de estados e prefeitos municipais; o direito ao voto para os analfabetos e voto facultativo para jovens com idade entre 16 e 18 anos; fim da censura aos meios de comunicação; o racismo passou a ser crime inafiançável, com pena de reclusão; a jornada de trabalho foi reduzida de 48 para 44 horas semanais; o direito de licença maternidade de 120 dias e licença paternidade de cinco dias. Enquanto, na ditadura, o movimento operário foi fortemente oprimido e lideranças sindicais foram presas e torturadas, com as novas leis, trabalhadores passaram a ter direito de greve e liberdade sindical. A nova Carta também estabeleceu o 
habeas data - processo que dá direito aos cidadãos todo o acesso a informações existentes sobre si em banco de dados de instituições públicas e governamentais; instituiu a independência entre os poderes Executivo, Legislativo (Senado e Câmara dos Deputados) e Judiciário; e substituiu o antigo decreto-lei pelas atuais medidas provisórias.

No entanto, conforme notamos na Figura 2, por meio das mãos trêmulas do presidente da Constituinte Ulysses Guimarães, a Carta também foi representada na charge como um peso. $\mathrm{Na}$ história, além da euforia, havia muitas dúvidas sobre o funcionamento, obediência e eficácia da nova Constituição. Uma reportagem publicada no dia 5 de outubro pelo Correio Braziliense é um bom exemplo. Com o título "Direitos sociais ainda criam expectativas", o especial trouxe um texto da jornalista Maria Lima, da editoria de política, onde muitos trabalhadores e empresários questionavam a nova Carta Magna. Entre os entrevistados, a reportagem contava a história de Leila Magalhães Caminha, professora e assessora de gabinete do Ministério da Saúde, que estava grávida, mas não queria usar os 120 dias de licença maternidade a que tinha direito porque estava com medo de perder o emprego. "Eu já ouvi dizer que já existem empresas exigindo atestado de ligadura de trompas no ato da contratação", diz. (Lima, 1988, p. 10). "Trabalhador nunca teve direito mesmo no Brasil! Não será agora que irá ter", completava o vigilante bancário Juvenal Menezes, na entrevista sobre as novas leis trabalhistas (Lima, 1988, p. 10). Embora otimista, a reportagem de Lima no Correio Braziliense trouxe outros questionamentos:

A nova lei de greve aprovada com direitos irrestritos vai mesmo paralisar este país com uma onda de movimentos liderados por sindicalistas irresponsáveis, como argumentam setores que tudo fizeram para manter a legislação mais restritiva? A licença paternidade de cinco dias vai acarretar transtornos e arruaças promovidas pelos trabalhadores que aproveitarão a folga para se entregar à cachaça, como disseram constituintes que tanto criticaram a iniciativa do pai Alceni Guerra? E o mercado de trabalho para as mulheres e mães profissionais, será mesmo afetado com a garantia da licença gestante de 120 dias? O Brasil sofrerá uma queda no mercado produtor de aço com a redução de oito para seis horas de trabalho nos turnos ininterruptos de revezamento? Estes são apenas alguns dos muitos argumentos utilizados pelos setores que trabalharam durante a Constituinte pela derrubada dos direitos sociais e trabalhistas, que, a partir de hoje, assam a fazer parte da nova realidade do trabalhador assalariado no Brasil. Entre perplexos, exultantes e receosos, os trabalhadores brasileiros saúdam a nova Carta e as conquistas que ela lhes traz. Agora é acreditar e esperar para ver que o país é capaz de absorver os avanços, sem previsões catastróficas ou sinistras (Lima, 1988, p. 10). 
A desconfiança do brasileiro na política e nas leis nacionais é histórica e perpassa inúmeras literaturas da nossa cultura. Roberto DaMatta (1986), em sua obra $O$ que faz o brasil, Brasil?, afirma que somos uma nação onde a lei sempre significa algo que é proibido, que não pode. Um país formal, capaz de tirar todos os prazeres e desmanchar todos os projetos e iniciativas. É alarmante constatar que a legislação diária do Brasil é uma regulamentação do não pode, a palavra não que submete o cidadão ao Estado sendo usada de forma geral e constante" (DaMatta, 1986, p. 100).

De fato, 1988 foi um ano de grande teste para a nova democracia, tanto para os cidadãos quanto para os políticos. Ao contrário dos Estados Unidos, que até hoje mantêm a sua primeira Constituição, feita em 1787 na esteira do seu processo de independência, o Brasil passava pela sétima. Das sete Constituições, quatro foram promulgados por assembleias constituintes, duas foram impostas - uma por D. Pedro I (1824) e outra por Getúlio Vargas (1937) - e uma foi aprovada pelo Congresso por exigência do regime militar. Todas partiram de cima para baixo, quase de surpresa, sem o envolvimento da população, que algumas vezes recebeu essas mudanças com displicência ou hostilidade. É por razões como esta que Sérgio Buarque de Holanda (1995) afirma, no seu clássico livro Raízes do Brasil, que a democracia no país foi sempre um lamentável mal-entendido. Para o autor, o Brasil, com seu homem cordial, aquele que age pelas leis do coração, com o predomínio do espaço privado sobre o público, das relações pessoais sobre as normas, não se apresenta como solo receptivo aos valores de igualdade da democracia:

A democracia no Brasil foi sempre um lamentável mal-entendido. Uma aristocracia rural e semifeudal importou-a e tratou de acomodá-la, onde fosse possível, aos seus direitos ou privilégios, os mesmos privilégios que tinham sido no Velho Mundo, o alvo da luta da burguesia contra os aristocratas. E assim puderam incorporar à situação tradicional, ao menos de fachada ou decoração externa, alguns lemas que pareciam os mais acertados para a época e eram exaltados nos livros e discursos (Holanda, 1995, p. 160).

A Assembleia Nacional Constituinte foi palco de diferentes correntes ideológicas, grupos de pressão e partidos políticos, fato que enriqueceu muito os grandes debates, mas que também fez com que os constituintes recebessem pressão de todos os lados: empresários, trabalhadores, religiosos, centrais sindicais, funcionários públicos, poder judiciário e 
empresas estrangeiras, entre outros grupos que queriam impor seus interesses e objetivos, tanto nas discussões quanto nas votações, em vez de um olhar coletivo. Esses sentidos são reforçados na última charge analisada (Figura 4).

\section{Efeito cascata}

Publicada em 19 de outubro de 1988, a imagem traz a Constituição de 1988 derrubando os ministérios como efeito dominó e representa o day after da promulgação e suas conquistas.

Figura 4: charge publicada no Correio Braziliense em 19/10/1988.

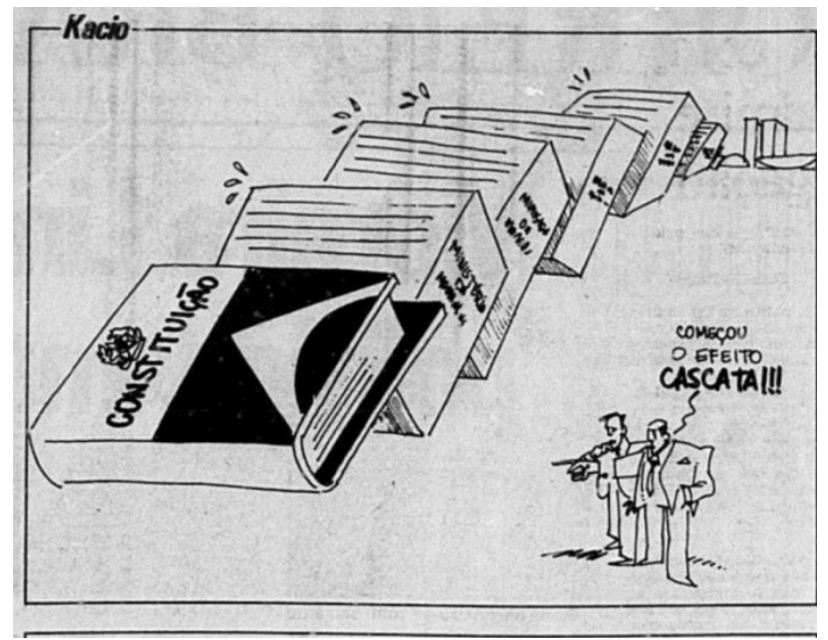

Autor: Kácio.

Como se tratava de uma Carta Magna que buscava romper as estruturas, talvez o chargista pretendesse mostrar que ela obrigaria uma mudança drástica de comportamento das autoridades ou um caos generalizado, sendo o Congresso Nacional o último a ser atingido pela mudança de paradigma do efeito dominó. Se a Constituição garantiu o direito de greve e ela já estava acontecendo legalmente, a imagem indica o peso da Carta na estrutura de governo, até então desacostumado a lidar com esse tipo de reivindicação, já que a redemocratização estava apenas começando. Essa representação de peso - uma relação intertextual com a charge da figura 2 - reforça o valor da Constituição, mas também as consequências do novo texto, tanto para o governo quanto para a sociedade. 
No contexto histórico, entre as reações causadas logo após a promulgação da nova Carta, o direito a greve levou a uma das maiores paralisações que o Brasil já teve, quando servidores públicos se organizaram em movimentos sociais e as greves tomaram conta de todo o país. Reportagem publicada pela Folha de S. Paulo, em 21 de outubro de 1988, afirmava que, em Brasília, a paralisação do funcionalismo já atingia, em 21 de outubro de 1988, 16 de um total de 22 ministérios. “Ao todo, mais de seis mil greves foram contabilizadas em toda a gestão Sarney" (Moreno, 2012).

De modo irônico, o efeito da imagem na charge da Figura 4 é reforçado pela fala de um das personagens, que usa a palavra "cascata" em caixa alta e em negrito. No entanto, o significado de "cascata", pode tanto representar que novos episódios estariam por vir, por conta das novas leis e direitos adquiridos pelos cidadãos, como também significar "mentira", "conversa fiada", sentido que a palavra cascata também tem no contexto brasileiro.

É importante observarmos as personagens da cena. Vestindo terno, gravata e usando lenço no paletó, a personagem principal sugere a representação de um patrão ou político, que aponta o dedo para Constituição e mostra suas implicações. Se pensarmos a personagem como um político crítico às novas conquistas, poderíamos até relacioná-lo a um constituinte do Centrão, grupo conservador e contrário às muitas teses progressistas debatidas na Assembleia Constituinte. O grupo dava apoio ao presidente José Sarney que, além de outros interesses, queria a todo custo manter os seis anos de mandato em vigor. Desde o início, a Constituinte se dividira nas questões da duração do mandato presidencial e da forma de governo. Enquanto uns defendiam o mandato presidencial de cinco anos, inclusive para o Sarney, outros propunham quatro anos para todos os presidentes, inclusive para o presidente em exercício. Com acordos e manobras políticas, o presidente Sarney conseguiu da Constituinte ficar no poder por cinco anos, evitando a redução para quatro.

Durante a Assembleia, o Centrão impôs uma alteração no regimento, na qual o campo da esquerda deveria reunir a maioria absoluta para garantir a permanência dos dispositivos aprovados em comissão. Esta mudança explica algumas contradições da Constituição, avançada em alguns temas e conservadora em outros. Ao pesquisar sobre a atuação do grupo na Constituinte, os autores Marcelino, Braga e Domingos (2009), afirmam que: 
apesar de ter se unificado com mais intensidade em questões político institucionais tais como o mandato de 5 anos para Sarney (com 84,3\% de seu integrantes votando favoravelmente) e a adoção do sistema presidencialista de governo ( $80,2 \%$ favoráveis), o "Centrão" comportou-se de maneira coesa e simetricamente oposta a outras forças atuantes na constituinte também em votações referentes aos direitos sociais dos trabalhadores (Marcelino; Braga; Domingos, 2009, p. 272).

A discussão sobre o tempo de mandato de Sarney e o interesse de Ulysses Guimarães em se candidatar à Presidência do Brasil atrapalharam o andamento do processo da nova Carta. No livro 1988: segredos da Constituinte, publicado em 2017 pelo jornalista Luiz Maklouf Carvalho, Sarney afirma, 30 anos depois, que, na época, a Constituição passou a ser uma caixa de pressão, lobby e transformou-se numa bacia das almas:

O que nós estamos vendo agora é o resultado da Constituição de 1988. Tanto que hoje nós temos noventa emendas constitucionais e mais de 1,5 mil em tramitação no Congresso. Só isso mostra o quanto a Constituição deixou a desejar. Aqui ela foi submetida a ceder grupos de interesse. Passou a ser mais fácil fazer-se uma emenda constitucional do que fazer uma lei (Carvalho, 2017, p. 49).

De fato, em 1988, o país já passava por uma turbulência, mas que foi agravada após a promulgação da Constituição. Cicatrizes do autoritarismo levaram a cogitar que, sem um pacto social ou econômico entre o governo, trabalhadores e empregados, haveria até mesmo um retrocesso político logo após a promulgação da nova Carta Magna, levando o presidente Sarney a declarar, no dia 26 de outubro, que ninguém viraria a mesa.

Nós vamos prosseguir na consolidação da democracia no Brasil até o fim do meu mandato. Vamos ter que conviver com esse período de acomodação. Naturalmente que no meio de toda transição existem sempre aqueles que querem se aproveitar do novo texto Constitucional para ocupar áreas aproveitando as janelas que a Constituição abriu (Correio Braziliense, 27 out. 1988, p.3)

A leitura da charge da Figura 4 se completa com a observação de André Petry publicada na coluna de opinião do jornal Correio Braziliense, no dia 21 de outubro de 1988. Com o 
título "Greve não cai do céu", ele afirma, que a agitação era uma síntese de direito e economia:

\begin{abstract}
Uns atribuem a onda de paralisações a um estranho surto pós-constitucional e não estão errados. Afinal, as entidades representativas dos trabalhadores não estavam querendo apenas um avanço formal quando deflagraram o corpo a corpo junto aos constituintes para consagrar na nova carta um dos direitos de greve mais liberais do mundo. Mesmo assim greve não cai do céu. A outra vertente não explica as paralisações do País a partir da promulgação da Constituição apenas. Percebe, além disso que o achatamento salarial não é um mero jargão sindicalista, mas uma realidade que afeta milhões de pessoas e que coloca o Brasil entre os países que pior remuneram seus trabalhadores. Essa agitação quase inédita do movimento sindical, portanto é uma síntese de direito e economia. E se o direito de greve concedido pela nova Constituição é, de fato, um dos mais abrangentes do mundo, ninguém pode ignorar que, do outro lado, a economia brasileira é de fato, uma das mais desorganizadas do mundo (Petry, 1988, p.2).
\end{abstract}

Aprofundando na cultura, análises de crises como essa, constituem um dos temas fundamentais da história social brasileira. Utilizando como referência os estudos de Holanda (1995), percebemos que as raízes de conflitos como esses podem estar, não só na relação confusa existente no Brasil entre o público e o privado, mas também na mudança do regime de trabalho das velhas corporações para o empregador moderno, que acarretou um desequilíbrio social, cujos efeitos permanecem vivos até hoje. A visão de Holanda (1995) corrobora com a de Ribeiro (2015) ao afirmar que o ruim aqui, e efetivo fator causal do atraso, é o modo de ordenação da sociedade, estruturada contra os interesses da população, desde sempre sangrada para servir a desígnios alheios e opostos aos seus.

Não há e nunca houve aqui um povo livre, regendo seu destino na busca de sua própria prosperidade. O que houve e o que há é uma massa de trabalhadores explorada, humilhada e ofendida por uma minoria dominante, espantosamente eficaz na formação e manutenção de seu próprio projeto de prosperidade (Ribeiro, 2015, p. 330).

\title{
Conclusão
}

Motta (2013) afirma que cada análise da narrativa jornalística segue um caminho próprio e individual. No nosso caso, estudar os significados produzidos pelas charges sobre os acontecimentos que envolvem a interpretação de um período histórico do Brasil, como a 
promulgação da Constituição Federal de 1988, não é apenas olhar o passado para refletir sobre o presente, mas conectar os acontecimentos difusos e desordenados do tempo jornalístico para entendermos a história.

Ao traçarmos o objetivo deste estudo, vimos que as charges publicadas pelo Correio Braziliense sobre a Constituição Federal de 1988 nos fornece elementos importantes para compreendermos nossas representações, posições e ideias durante o processo histórico de redemocratização e elaboração da Carta Magna.

Por meio da análise crítica da narrativa, percebe-se que a primeira charge destaca puramente a fase utópica constitucional. Até por conta da forte memória da época, de um Estado autoritário, intolerante e violento, a Carta foi representada na primeira imagem como um símbolo maior de esperança pela busca de um Estado democrático de direito, uma nova chance de transformação. No entanto, com o desenrolar dos fatos e novos episódios, a representação da Constituição de 1988 nas páginas do Correio Braziliense começou a ganhar traços que permitissem o questionamento de sua obediência, funcionalidade e futuro. Com a incerteza de se o Estado seria realmente capaz de cumprir com as promessas constitucionais.

Mergulhando nas águas do nosso passado, é possível afirmar que tivemos avanços em muitos aspectos, enquanto em outros, nem tanto. Na conta do atraso político e da dívida social ainda há incontáveis débitos, como os problemas dramáticos de desigualdade social, moradia, segurança, saúde e educação. Não é exagero afirmar que a nossa história tem como ponto central a luta do cidadão contra o Estado arbitrário.

O caminho já foi apontado pela Constituição, que completou 30 anos em 2018: as transformações só serão possíveis por meio da democracia. Nem sempre a maturidade foi alcançada, mas a Carta Maior mantém viva a lembrança de que o povo brasileiro já percorreu um longo percurso de conquistas e vitórias em busca de um futuro que parece nunca chegar 


\section{Referências}

ANGELO, V. A. Constituição de 1988: Contexto histórico e político. UOL. Disponível em https://educacao.uol.com.br/disciplinas/historia-brasil/constituicao-de-1988-1-contexto-historico-epolitico.htm. Acesso em: 31.05.2018.

AUMONT, J. A imagem: olhar, matéria, presença. Lisboa: Texto \& Fotografia, 2011.

BERGER, P. L.; LUCKMANN, T. A Construção Social da Realidade. Petrópolis-RJ: Vozes, 2012.

BURKE, P. Testemunha Ocular: história e imagem. São Paulo, SP: Unesp, 2017.

CANCIAN, Renato. Governo José Sarney (1985-1990): Nova Constituição e crise econômica. UOL. Disponível em https://educacao.uol.com.br/disciplinas/historia-brasil/governo-jose-sarney1985-1990-nova-constituicao-e-crise-economica.htm. Acesso em 15.05.2018.

CARVALHO, L. M. 1988: segredos da Constituinte. Rio de Janeiro: Record, 2017.

CORREIO BRAZILIENSE. Garantias indispensáveis. Correio Braziliense, Brasília, 2 fev. 1987. Opinião, p.4

CORREIO BRAZILIENSE. Sarney garante: ninguém vira a mesa. Correio Braziliense, Brasília, 27 out. 1988. política, p.3.

DAMATTA, R. O que faz o brasil, Brasil?. Rio de Janeiro: Rocco, 1986.

FERNANDES, P. J. Caricatura e Cartoon em Portugal: Humor sem contensão no Portugal Contemporâneo, in Humor, Direito e Liberdade de Expressão. Lisboa, Centro de Estudos Judiciários, 2016, p. 215-235.

FLÔRES, O. A leitura da charge. Canoas: Ed. ULBRA, 2002.

FONSECA, J. Caricatura: a imagem gráfica do humor. Porto Alegre, RS: Artes e ofícios, 1999.

FONSECA, V. P. S. O acontecimento como notícia: do conceito à prática profissional. In:

BENETTI, Marcia; FONSECA, Virginia Pradelina da Silveira (orgs.). Jornalismo e acontecimento: mapeamentos críticos. Florianópolis: Insular, 2010.

HALL, S. The work of representation. In: HALL, S. (org.). Representation: cultural representations and signifying practices. London: Sage Open University, 2009.

HOLANDA, S. B. O homem cordial. Rio de Janeiro: Companhia das Letras, 1995.

KELLNER, D. A cultura da mídia. Bauru, SP: EDUCS, 2001.

LIMA, M. Direitos Sociais ainda criam expectativas. In. Correio Braziliense, Brasília, 5 out. 1988. Edição Especial da Constituição, p.10.

MARCELINO, D.; BRAGA, S. B.; DOMINGOS, . Parlamentares na Constituinte de 1987/88: uma contribuição à solução do "enigma do Centrão". Revista Política Hoje, Vol. 18, n. 2, 2009. 
MIANI, R. A. Charge Editorial: Iconografia e pesquisa em história. Disponível em: < http://www.uel.br/revistas/uel/index.php/dominiosdaimagem/article/view/20649/15669>. Acesso em 20.01.18.

MORENO, J. B. A História de Mora. O Globo. Disponível em https://oglobo.globo.com/brasil/ahistoria-de-mora-1988-greves-de-servidores-param-pais-5834848. Acesso em: 21.05.2018.

MOTA, C. L. A narrativa semiótica da imagem. In: MOTA, Célia Maria Ladeira; MOTTA Luiz Gonzaga; CUNHA, Maria Jandyra (Orgs). Narrativas midiáticas. Florianópolis: Insular, 2012.

MOTTA, L. G. Análise crítica da narrativa. Brasília: Universidade de Brasília, 2013.

PETRY, A. Greve não cai do Céu. In: Correio Braziliense, Brasília, 21 out. 1988. Opinião, p.2.

QUÉRÉ, Louis. Entre fato e sentido: a dualidade do acontecimento. In: Trajectos. Revista de Comunicação, Cultura e Educação, Lisboa. No. 6, 2005, p. 59-76.

RIBEIRO, D. O povo brasileiro: a formação e o sentido do Brasil. São Paulo: Global, 2015.

RODRIGUES, A. D. 'O Acontecimento'. In: TRAQUINA, Nelson. Jornalismo: Questões, Teorias e "Estórias". Lisboa: Editora Veja, 1993.

ZWEIG, S. Brasil, o país do futuro. Porto Alegre, RS: L\&PM, 2013.

\section{Os autores}

Paulo Henrique Soares de Almeida é doutorando e mestre em Comunicação pela Universidade de Brasília (UnB). Bolsista da Coordenação de Aperfeiçoamento de Pessoal de Nível Superior (Capes).pauloalmmeida@gmail.com

Célia Maria Ladeira Mota é doutora em Comunicação, pesquisadora associada ao Programa de Pós-graduação da Faculdade de Comunicação da Universidade de Brasília. cladmota@gmail.com 